\title{
Comparative Study of Supply Chain Relationships, Mass Customization, and Organizational Performance between SME(s) and LE(s)
}

\author{
Thawatchai Jitpaiboon \\ Miller College of Business, Ball State University, USA \\ E-mail: tjitpaiboon@bsu.edu \\ Sushil Sharma \\ Miller College of Business, Ball State University, USA \\ E-mail: ssharma@bsu.edu
}

Received: November 2, 2012

Accepted: December 17, 2012

Online Published: December 19, 2012

doi:10.5430/jbar.v1n2p139

URL: http://dx.doi.org/10.5430/jbar.v1n2p139

\begin{abstract}
The influence of information technology (IT) exceeds in providing financial and operational support to organizations. ITis being used to facilitate customer and supplier involvement indesigning specialized product offerings, implementing process improvements, enhancing manufacturing flexibility, and controlling manufacturing operations. Together, these advances are enabling firms to not only customize their product offerings (i.e. mass customization) and market the mat prices close to those quoted by traditional mass producers but also contribute to organizational performance (OP). Organizational performance (OP) is the extent to which a firm fulfills its market and financial goals.

While much research on mass customization has been reported in the literature, empirical studies investigating the impacts of IT on creating cooperative and integrative relationships with customers and suppliers and the impacts of these relationships on the level of mass customization and organizational performance are sparse and represent a missing link in manufacturing research. The contributions of this study include supply chain relationship in SMEs and LEs, mass customization, and organizational performance. Using data collected from 220 manufacturers, this study finds that large firms (LEs) have higher levels of cooperative relationships with suppliers and customers and enjoy higher levels of mass customization and organizational performance than small and medium size firms (SMEs).
\end{abstract}

Keywords: Mass customization, Organizational performance, Supply chain relationship, Large enterprises (LEs), Small and medium enterprises (SMEs)

\section{Introduction}

Mass customization (MC) results when a firm produces a variety of customized products quickly, on a large scale at costs comparable to those of traditional mass producers (Pine, 1993). MC is a way for firms to address new market realities while duplicating the efficiencies of traditional mass production (Pine, 1993; Tseng and Piller, 2003; Piller, 2003; Frank and Piller, 2003). Currently, the literature reports three important points regarding MC which are of interest to this study: (1) the degree to which a firm coordinates activities with suppliers and customers (e.g., Supply Chain Relationships) and MC capability; (2) the relationship between MC capability and organizational performance (OP); and (3) the relationship between supply chain relationships and OP. Concerning the first issue, O'Grady (1999) reports the existence of three powerful forces driving the success of MC: (1) the accelerating rate of technological change; (2) the increasing sophistication of products; and (3) empowered customers demanding greater product variety due to increasing global competition and growing disposable incomes. Many companies are increasingly using information technology (IT) to directly connect with their customers thus enabling the companies to know individual customer preferences for tailoring products accordingly, and producing them in a timely manner at reasonable costs (O'Grady, 1999; Sophie Lee et al., 2000). IT also allows firms to work closely with suppliers to coordinate product designs, process improvements, and on-time deliveries so that strategic goals and customization objectives are achieved (Tracey et al., 1999). IT can facilitate customer involvement in designing specialized 
products that enhance flexibility, implement process improvements, involve suppliers, and control manufacturing operations. Firms are then able to customize products and sell them at lower prices. Customers reap the benefits from using the specialized products (Duray et al., 2000; Tu, Vonderembse, \& Ragu-Nathan, 2001; Tu, Vonderembse, \& Ragu-Nathan, 2004). In this MC effort, IT becomes the backbone of an integrated supply chain by helping synchronize the actions of many diverse companies that increase customer value. The literature reports the existence of many examples of supply chain relationships and resulting MCs. For example, Piller et al. (2004) asserted that a firm offering customized products to acquire profits is largely due to the higher degree of interaction among a firm and its partners, including both customers and suppliers. Gilmore and Pine (1997) suggested that one of four approaches for achieving customization is through collaboration. Yassine et al. (2004) investigated the role of IT affecting customized product design. In their theoretical framework, coordination was found to influence product development capability for customization.

The literature has reported a higher degree of association between MC capability and OP. Moving from a traditional mass production paradigm to a mass customization paradigm, firms can enhance their ability to satisfy customized demands and improve performance by involving customers and suppliers at early stages in their product design and manufacturing processes (Rabinovich, Dresner, and Evers, 2003). Information gained from data provided by customers and suppliers can help firms:(1) avoid exclusively relying on forecasting methods;(2) reduce the value of their inventories and the cost of carrying them by postponing the final configuration of the product until customer requirements become clearer; and (3) reduce the costs associated with the avoidance of product obsolescence (Pine, 1993; Alderson, 1957). The literature also reports a higher degree of association among supply chain integrated (SCI) relationships and OP. For example, optimizing linkages among value-adding activities is the core purpose of SCI and such integration should engender superior performance (Tan et al., 1998; Frohlich and Westbrook, 2001). Having an integrated supply chain relationship provides significant competitive advantages including the ability to outperform rivals on both price and delivery (Lee \& Billington, 1992). Frohlich and Westbrook (2002) and Frohlich (2002) confirmed this relationship by studying the effects of web-based integration on demand affecting supply chain management's OP.

Much research on $\mathrm{MC}$ reports that the significant contribution of integrated supply chain relationships to the success of MC is the providing of evidence that supply chain relationships and MC may lead to better OP. The purpose of this study is to extend this research further by investigating the effects of the size of organizations on these relationships. This study seeks to explore the various ways in which Small and Medium Enterprises (SMEs) and Large Enterprises (LEs) affect these relationships. Fisher (1997) argues that these two types of firms inadvertently fall into the trap of mismatching desired supply chain objectives which may lead to them adopting different mass customization strategies. The study contends that SMEs and LEs adopt different mass customization strategies largely due to two conflicting perspectives: (1) LEs are better at providing mass customization (according to the proponents of LEs) and (2) SMEs are better at providing mass customization (according to the proponents of SMEs).

First, Quayle (1999) reported that only about 25 percent of SMEs give significant attention to improving supply chain issues affecting them because of a perceived inability to shape or influence these supply chain systems. Several studies have reported that SMEs do understand the importance of SCI; however, because of lacking financial resources and/or market knowledge, they choose not to implement supply chain management (SCM) systems (Barringer, 1997; Caskey et al., 2001).As a result, SMEs may resist offering products to customers because of having limited power and capital to control the required resulting supply chain relationships. Therefore, with this view, SMEs may choose to offer limited options instead of full options. On the other hand, large enterprises (LEs) have been at the forefront of initiating and implementing supplier-customer relationships (Harrison, 1992; Blenckhorn \& Noon, 1990; O'Neal \& Bertrand, 1991). LEs are more likely to form stronger relationships with their customers and suppliers through greater purchasing power as they are mainly interested in minimizing risk by using single or dual-sourcing (Sinclair, Hunter, \& Beaumont, 1996). As a result, LEs are likely to perform better in offering MC to customers because of having enough purchasing muscle to force suppliers to adopt detailed product specifications and certain quality management techniques and practices as a contractual condition (Lascelles \& Dale, 1989). In some situations, LEs force their suppliers to implement systematic forms of supplier-customer relationships that help enhance the process of MC (Zipkin, 1991). For example, suppliers are expected to invest in such technologies as e-commerce, ERP systems, flexible machines, and CAD equipment that help expand the ability of their customers to customize their choices (Matthyssens \& Bulte, 1994).Suppliers seldom take a proactive role in initiating or implementing a supplier-customer relationship (Bertrand, 1986). Rather they concentrate on complying with LEs' requirements in order to remain in the shrinking LEs' supplier base. 
The second viewpoint favors SMEs in providing better MC. This study speculates that because SMEs lack the power to initiate supply chain relationships, they choose to form strategic alliances with customers and suppliers rather than being aggressive. Several studies report that SMEs gain significant benefits of closer customer-supplier relationships (Kalwani \& Narayandas, 1995; Giunipero \& Brewer, 1993; Akacum \& Dale, 1995). Research by Bradley, Meyer, and Gao (2006) shows that the SME's attitude toward supplier-customer relationships may enhance the longevity of the relationship, the strength of the supplier-customer bonds, the number of its supplier-customer relationship customers, and the likelihood of bringing new customers aboard. Although SMEs might not be able to influence the suppliers and customers to implement systems that enhance the process of MC, achieving higher levels of MC is possible. Because of being part of small supply chains, SMEs are able to devote resources to identify customer needs and work closely with suppliers to fine tune products to match those needs. Suppliers are willing to work with SMEs as opposed to LEs because they have a sense of security in sustaining their supplier-customer relationship. Working with SMEs, customers also enjoy the sense of commitment and fast response time. SMEs are able to offer a greatly detailed product that is customized to fit customer needs.

There is no definite answer to this paradox; however, this study may shed some light on the issues regarding:

(1) Is the level of MC-driven performance different for SMEs than for LEs?

(2) Is the extent of supply chain relationships-driven MC different in SMEs compared to LEs?

(3) Is the extent of supply chain relationships-driven performance different in SMEs compared to LEs?

Figure 1 provides a visualized depiction of these research questions.

Although SMEs might not be able to influence supply chain systems as a whole, their participation in SCI processes is crucial for the success of a given supply chain provided that they are supporters of LEs. Therefore, understanding how managers' from SMEs and LEs perceptions differ on the issues of supply chain relationships, MC, and organization performance may shed some light for managers to adjust their integration strategies appropriately. This study will contribute to the research and practice in the areas of $\mathrm{MC}$ being the first that takes into account the differences between SMEs and LEs on issues regarding supply chain relationships, MC, and OP. Understanding the supply chain relationships concept is important to the survival of companies that implement MC as well as understanding differences between SMEs and LEs which may help firms choose appropriate strategies to implement based on its environment.

\section{Theoretical framework}

A theoretical framework can be formulated based on an extended literature review. Lau (1995) states that MC may be the basis for the next "industrial revolution" as it encourages and enables firms to design and produce specialized products on a large scale without sacrificing efficiency. Pine (1993), Tu et al. (2001), and others claim that MC is the ability to design, produce, and deliver products quickly to meet specific customer needs at prices close to those of traditional mass production. The foundation of MC is the ability to achieve customer responsiveness, cost efficiency, and high volume production, simultaneously.

Researchers suggest that MC is possible because of the use of such technologies as flexible manufacturing systems, modular product structures, and the Internet to reduce the tradeoffs between variety and productivity and provide transparent communications between a firm and its trading partners (Ahlstrom \& Westbrook, 1999; Jiao \& Tseng, 1996; Tu et al., 2001). However, the current literature does not provide an explanation for the missing link between supply chain relationships between a central firm with its trading partners both upstream and downstream (e.g., supplier integration and customer integration) and the MC capability of the central firm. This paper argues that the success of MC is not from the central firm and its customers' relationship alone. Rather it is largely dependent on the central firm's effectiveness at fully utilizing its supply chain potential. Effective supply chain relationships enhance transparent communication, which is a key to a successful MC because information flows seamlessly from one supply chain entity to the next. Figure 1 illustrates that MC may be affected by the firm's ability to build supply chain relationships with its trading partners (suppliers and customers). Zipkin (2001) argues that a firm must interact with its customers to gather specific information so that it can define and transform customer expectations into product specifications. Simultaneously, a firm must communicate and coordinate activities with its suppliers so that they can respond quickly and effectively to the needs of the ultimate customer (Petersen et al., 2005a; Petersen et al., 2005b; Sanders, 2005; Sanders \& Premus, 2005). By developing enterprise-wide information systems that provide a seamless integration of data flows between the central firm and its trading partners, firms make better decisions. They participate in an integrated process built on cooperation and co-creation which results in a high degree of integration (Piller et al., 2004). 
Insert Figure 1 here

\subsection{Customer and Supplier Integration}

The front-end of the framework explains a supply chain relationship's construct. Lambert and Garcia-Dastugue (2006, p.150) point out that "failure to integrate activities effectively will hinder management's ability to make the entire value system work (Normann \& Ramirez, 1993)." Integrative relationships can be facilitated by the continuous automation and standardization of internal logistics functions, efficient information sharing, and strategic linkages with suppliers and customers. Scholars such as Narasimhan and Kim (2002) have examined outcomes of such integration, including performance. Their instrument has three dimensions: (1) integration across the supply chain; (2) a company's integration with customers; and (3) a company's integration with suppliers. Considering the interface of IT, Frohlich and Westbrook (2002) and Frohlich (2002) studied the effect of web-based integration on operational performance. They measured web-based integration as e-integration with suppliers and customers. This study builds upon these studies to explore customer integration and supplier integration. The instruments for these measures are adapted from Frohlich and Westbrook (2002), Frohlich (2002), Peterson et al. (2005a), Peterson et al. (2005b), and Koufteros et al. (2005).

Customer integration (CI) is the extent to which purchasers take part in value-creating activities and processes that previously had been in the domain of a firm (Wikstrom, 1996). This includes assessing customer needs and tailoring internal activities to meet them (Koufteros et al., 2005). When firms know their customers and become committed to understanding and meeting their needs, a strong bond is forged between firms. Integration ensures that the voice of the customer is heard and incorporated into a firm's outputs.

Supplier integration (SI) is the extent to which vendors form cooperative relationships by taking part in activities and processes that had previously been in the domain of the firm. It is characterized by a long-term commitment between the collaborators, open communication, and mutual trust. Supplier partnerships involve participants early in the product life cycle thus ensuring early supplier involvement in product design and access to superior supplier technologies (Narasimhan \& Das, 1999; Petersen et al., 2005a; Petersen et al., 2005b).

\subsection{Mass Customization}

The middle part of the framework shows the MC construct. Boynton et al. (1994) further developed the MC concept put forth by Pine (1993) by comparing it with mass production, invention, and continuous improvement in a product/process change grid. This illustrates the movement away from mass production toward MC. Recognizing the important role of speed, Tu et al. (2001) define MC as the ability to produce differentiated products with cost effectiveness, volume effectiveness, and responsiveness. Other authors such as Steger-Jensen and Svensson (2004) describe $\mathrm{MC}$ as involving processes and organizational structures aimed at providing varied and many times individually customized goods and services at low costs typically found in mass-produced products. Consistent with the literature (Kotha, 1995; Duray et al., 2000; Silveira et al., 2001; Tu et al., 2004a; Tu et al., 2004b; Steger-Jensen and Svensson, 2004), this study develops a measure of MC capability manifested in customization volume effectiveness, the ability to add product variety without sacrificing production volume, customization responsiveness, the ability to reorganize manufacturing process quickly in response to customer requirements, and customization cost-effectiveness, the ability to customize products without increasing manufacturing costs. This study defines MC as the extent to which a firm demonstrates the ability to produce a variety of customized products quickly, at a scale and cost comparable to mass production.

\subsection{Firm Performance}

The back-end of the framework shows the organizational performance construct. Firm performance (FP) is the extent to which a firm fulfills its market and financial goals. Wisner (2003) studies the effects of supply chain management strategy on FP, which can be measured by market share, return on assets, overall product quality, overall competitive position, and overall customer service level. FP is a key outcome measure given that a firm's manufacturing capabilities such as cost, quality, flexibility, and delivery can be linked to its competitive priorities (Taps \& Steger-Jensen, 2007). Rosenzweig et al. (2003) used four items to measure business performance including pre-tax return on assets, percentage of revenues from new products, overall customer satisfaction, and business unit sales growth. Frohlich (2002) used two items to measure e-business performance: annual percent of procurement using the Internet and annual percent of sales/turnover using the Internet. Narasimhan and Kim (2002) used sales growth and market share growth with a three year look-back, profitability, return on investment, return on assets, revenue growth, financial liquidity, and net profit to measure FP. With concern for rigor and consistent with previous scholarly work, 
herein FP is measured by customer retention rate, sales growth, return on investment, production throughput time, and overall competitive position.

Table 1 provides a definition for each variable in Figure 1 as well as important references. Appendix A shows the final survey items used in this study. The following sections discuss these variables and propose the hypotheses illustrated in the framework.

Insert Table 1 here

\section{Hypotheses Development}

\subsection{Supply Chain Relationships in SMEs vs. LEs}

Numerous SCM studies have found that supply chain relationships affect a firm's levels of mass customization. Unfortunately, limited research exploring the subject exists from the perspective of SMEs versus LEs. This study contends that LEs have been originators at initiating and implementing supplier-customer relationships through the formation of supply chain tiers to guarantee their having enough purchasing muscle to force suppliers to adopt mass customization practices as a contractual condition (Harrison, 1992; Blenckhorn \& Noon, 1990; O'Neal \& Bertrand, 1991; Sinclair, Hunter, \& Beaumont, 1996; Lascelles \& Dale, 1989).With stable revenue and profit sources LEs can more easily justify implementing costly supply chain systems to enhance mass customization. For major original equipment manufacturers (OEMs), for example, establishing a supplier-customer relationship provides a MC advantage by reducing the overall cost of the final product (Bradley, Meyer, \& Gao, 2006). Dilts and Prough (1989) observed that SMEs often face severe resource constraints, lack managerial expertise, and tend to pursue less aggressive customization options when offering products to customers. As a result, many SMEs may not have internal supply chain foundations upon which supplier integration strategies and processes can be based (Wagner, 2003). From this observation, the following hypothesis can be drawn.

\section{H1: LEs have a higher level of SCR-mass customization relationships than SMEs}

Since SME supply chains are much simpler, fewer and shorter, the process of collaborating and sharing information across the supply chain is much simpler than that of LEs. Unlike LEs, SMEs avoid using distribution centers or wholesalers. Instead, they usually deal with retailers, or, in many cases, directly with end-customers. The practice might help SMEs strengthen their relationships with customers (Morrissey and Pittaway, 2006); however, LEs tend to build stronger relationships with customers because they can offer better overall benefits to customers, which eventually will help them reduce overhead and improve operational effectiveness (Kalwani \& Narayandas, 1995), increase sales volume, gain longer-term business agreements, and establish prompter payments (Giunipero \& Brewer, 1993; Akacum \& Dale, 1995).

LEs appear to develop stronger relationships with suppliers, enabling them to procure quality goods and services at lower costs. Shin et al. (2000) and Petersen et al. (2005) reported that improvements in supplier relations significantly improved delivery, quality of goods and services, and financial performance. LEs usually prefer multi-tier suppliers in their supply chain and close integration is a key to their success. Compared to SMEs, LEs have capabilities to build long-term relationships with many critical suppliers in the industry due to the high volume and value of purchases. Having strong financial resources and IT capabilities also helps to strengthen this relationship. Wal-Mart has deployed the Retail Link System to integrate their internal system with all of their supplier systems in order to share all operating product development and inventory levels information. These discussions lead to the following hypotheses.

H2: LEs have a higher level of customer integration (CI)-operational performance relationship than SMEs

H3: LEs have a higher level of supplier integration (SI)-operational performance relationship than SMEs

\subsection{Mass customization in SMEs vs. LEs}

Morrissey \& Pittaway (2006) revealed that the basic disadvantage for SMEs is their smaller size and lack of power when trying to offer MC to customers. Mudambi et al. (2004) confirmed that size asymmetry was a determining factor affecting the levels of negotiation between a purchasing firm and its suppliers. Ultimately, LEs were able to dictate their preferred degree of closeness in their relationship with their smaller customers. In addition, LEs were able to negotiate in the higher level of quality and detailed specifications from the suppliers thus benefiting more from the mass customization. Scully and Fawcett (1994) conducted a survey of 500 US firms to compare and contrast International Sourcing (IS) activities between SMEs and LEs and confirmed that SMEs were very limited in expanding their IS capabilities to support mass customization. Although some SMEs realized the benefits of such capabilities, they were reluctant to do so. 
Regarding the purchasing power, Axelsson \& Larsson (2002) asserted that, irrespective of the source, power can result in compliance and can drive the adoption of new practices. LEs can force suppliers to expand their envelope to adopt new systems which enhance the mass customization process. In this position dominant buyers are able to make demands, not only for the deliveries and quality of the product, but for the sake of mass customization (Holmlund \& Kock, 1996; Sauders, 1997). The confirmation from these studies leads to the following hypothesis:

H4: LEs have a higher level of mass customization-organization performance relationship than SMEs

Insert Figure 2 here

\section{Research methodology}

Instrument development for customer integration, suppler integration, mass customization, and organizational performance constructs was carried out in three phases: (1) item generation; (2) pilot study; and (3) large-scale data analysis. An extensive literature review was conducted to identify the domain of the major constructs. Based on theory development and a literature review, construct definitions and initial items were generated. Next, a pilot study was conducted three times using the Q-sort method. Analysis of inter-rater agreement helped to identify weaknesses in construct definitions as well as bad items. Third, a large-scale data set was collected and analyzed to validate the instruments and test the model.

\subsection{Item generation and pilot study}

A list of initial items for each construct was generated based on theory development and a comprehensive literature review. The number of items used in each category was 6 customer integration, 6 supplier integration, $9 \mathrm{MC}$, and 5 organizational performance. Scales for the items were five-point Likert-type scales where 1 = "Strongly Disagree", 2 = "Disagree", 3 = "Neutral", 4 = "Agree", 5 = "Strongly Agree", and NA = "Not Applicable, or Do Not Know". Items for the various constructs were reviewed by five academicians and re-evaluated through structured interviews with two practitioners to check the relevance of each construct's definition and clarify wordings. Based on the feedback from the academicians and practitioners, redundant and ambiguous items were either modified or eliminated. New items were added when necessary.

\subsection{Survey methods, data collection, and sample characteristics}

A cross-sectional self-administered mail survey was conducted. The sampling frame was obtained from the Society of Manufacturing Engineers (SME). Of 4,000 mailed questionnaires, 579 did not reach the targeted respondents because of bad addresses. A large number of respondents (235) wrote a refusal on their returned survey and 3,171 questionnaires did not return surveys. In addition, 14 questionnaires were returned empty. Therefore, the number of complete and usable responses was 220, representing a response rate of $6.94 \%$ (calculated as 220/3,171).

\subsection{Measurement model results}

Content validity was determined through a comprehensive review of literature, Q-sort, and assessment by a panel of practitioners and academics to ensure that measurement items covered the domain of the construct. A confirmatory factor analysis (CFA) using structural equation modeling method - AMOS version 16 was conducted to refine the measurement models.

Convergent validity can be assessed by examining the individual item loadings on their theorized latent variables (Swafford et al., 2006). Table 2 displays the standardized item loadings for the measurement models under study. Five items with low factor loadings were dropped at this stage (2 from CI, 2 from MC and 1 from FP; see Appendix A). All the items kept are sufficient to demonstrate convergent validity.

\section{Insert Table 2 here}

Cronbach's $\alpha$, composite reliability, and average variance extracted (AVE) were used to test reliability. An additional test of convergent validity is provided by assessing average variance extracted (AVE) values for each construct (Segars, 1997). A review of Table 3 reveals that all constructs display AVE values $>0.50$, thus providing further evidence of convergent validity.

\section{Insert Table 3 here}

Evidence of discriminant validity exists if the AVE of each construct is greater than the square of the correlations (Braunscheidel and Suresh, 2009). An acceptable alternative suggests that the square root of a construct's AVE should be greater than the correlations between constructs (Chin, 1998; Fornell and Larcker, 1981; Koufteros, 1999; Koufteros et al., 2001). Table 4 displays the correlations between all latent constructs. The square root of the AVE 
for each construct is bolded and can be found on the diagonal. Each is greater than the value of the correlations in its corresponding row and column.

Insert Table 4 here

\subsection{Demographic information}

Table 5 shows sample characteristics of respondents by job titles, job functions, and level of education.

Insert Table 5 here

\subsection{Test of Non-Response Bias}

Of the 220 surveys returned, 148 responses were from the first mailing and 72 were from a second follow up mailing. Because the original data sample from the SME did not contain descriptive information of the targeted respondents, there is no way to test the non-responses bias compared to the population. Therefore, the non-response bias was tested by comparing the mean value in the first and second waves as assessing the second wave is equivalent to non-responders. Chi-square tests were performed on sales volume and some of the constructs, and t-test procedures were performed on the summated scale of each construct (Armstrong and Overton, 1977). The results in Table 6 also show mean values of variables. There appears to be no significant difference in the data between these two groups.

\section{Hypotheses Testing}

Insert Table 6 here

To test hypotheses, linear regression analysis is applied. The following show the regression models tested for each hypothesis.

$$
\begin{aligned}
& \mathrm{MC}=\beta_{0}+\beta_{1} \mathrm{SCR} * \mathrm{~S}+\mathrm{r} \\
& \mathrm{OP}=\beta_{0}+\beta_{1} \mathrm{CI} \mathrm{S}+\mathrm{r} \\
& \mathrm{OP}=\beta_{0}+\beta_{1} \mathrm{SI} \mathrm{S}+\mathrm{r} \\
& \mathrm{OP}=\beta_{0}+\beta_{1} \mathrm{MC} * \mathrm{~S}+\mathrm{r}
\end{aligned}
$$

Where: $\quad \mathrm{MC}=$ mass customization

$$
\begin{aligned}
& \mathrm{OP}=\text { operation performance } \\
& \mathrm{SCR}=\text { supply chain relationships }
\end{aligned}
$$

$\mathrm{SI}=$ supplier integration

$\mathrm{CI}=$ customer integration

$\mathrm{S}=$ the size of companies

$\mathrm{r}=$ the residual

$\beta_{0}$ and $\beta_{1}=$ intercept and slopes

The size of companies $(\boldsymbol{S})$ is a categorical item representing the number of employees in the company. This variable was originally categorized into six stratifications, namely: 1-50 employees; 51-100 employees; 101-250 employees; 251-500 employees; 501-1000 employees; and over 1000 employees. It is then coded into nominal scale variables with 0 value representing SMEs (the number of employees less than or equal to 500 employees) and 1 value representing LEs (the number of employees more than 500 employees).

\section{Hypothesis testing results}

All hypotheses were tested using linear regression methodology. Table 7 shows the results of the hypothesis tests.

Insert Table 7 here

Regarding $\mathrm{MC}$ as a dependent variable, the results (Table 6) suggest that the level of MC differs significantly between SMEs and LEs and LEs are likely to have higher MC than SMEs $(t=4.365)$. The obtained results support hypothesis 1 that states LEs have a higher level of SCR-MC relationship than SMEs.

With OP as a dependent variable, the regression results support hypothesis 2 that states that LEs have a higher level of CI than SMEs $(t=2.602)$. The results imply that LEs can form a better relationship with customers than SMEs can. The results also show that LEs are likely to have better SI than SMEs $(t=2.838)$; therefore, the results support hypothesis 3, which states that LEs have a higher level of SI than SMEs. 
With regard to the relationship between MC and OP, the results support hypothesis $4(t=3.362)$, which states that LEs have a higher level of MC than SMEs.

\section{Discussion and conclusions}

This research contributes to the literature in supply chain management and SME research. It suggests that three main issues are important: (1) supply chain integration; (2) the size of companies (SMEs vs. LEs); and (3) the level of mass customization (MC). The results in this study reinforce important roles of SCI previously reported in the literature (Ragatz et al., 1997; Simchi-Levi et al., 2003; Narasimhan \&Kim, 2002; Vickery et al., 2003). Efficient SCI leads to the intensification of key practical resources and subsequently drive much more significant performance improvement by enabling the sharing of special resources and technological knowledge for particular supply chain capabilities from supply chain partners. However, the previous studies have focused on SCI in general and discarded issues regarding the differences between SMEs and LEs. This study emphasizes the importance of SMEs in helping LEs to reach potential performances. From the results, the following managerial implications can be drawn.

The contributions of this research arise from combining the three research directions 'SCR', 'SMEs vs. LEs', and 'Mass Customization'. This study emphasizes the differences between SMEs and LEs in contributing to organizational performance (OP), overall supply chain relationship (SCR), upstream integration (SI), downstream integration (CI) in a supply chain, and the extent to which the organization adopts mass customization (MC). The results prove that LEs perform better than SMEs in all dimensions (e.g., OP, SCR, SI, CI, MC). The level of SCR tends to increase with the size of organizations. Two implications could be drawn from this finding. First, larger organizations view supply chain integration as a strategically important tool to compete successfully in the market place. Firms such as Wal-Mart and GM spent billions of dollars implementing enterprise resource planning systems (SAP) to guarantee transparent communication. By doing so, they can achieve accurate transactions, highly efficient processes, high production throughput time, and high customer retention rate. Second, LEs also have much needed resources and high bargaining power to implement supply chain systems. Conversely, SMEs are less likely to view SCR as an important part of their businesses. This is not surprising because SCR is a capital intensive approach. As a result, SMEs have little or no power to influence supply chain systems and lack resources to implement supply chain integration projects. This hurts not only SMEs, but also LEs because most LEs need SMEs to supply their products. Therefore, LEs might take a larger role to help SMEs to achieve full participation in supply chain systems. After all, supply chain integration is motivated by the recognition of interdependency between suppliers and customers.

LEs also show better supplier integration and customer integration than SMEs. According to Zipkin (1991), LEs are likely to initiate the relationship with suppliers based on arm's length relationships (the buying power LEs have over their suppliers). By building long-term relationships with suppliers, LEs are moving from arm's length relationships toward strategic supplier relationships or 'the supply base' (Jayaram, Kannan, and Tan, 2004). Examples include Intel, Proctor and Gamble, Hewlett Packard, and Wal-Mart. Wal-Mart, for example, provides a good illustration of a firm that has built structural mechanisms that help add key supply chain members such as Proctor and Gamble to its supply base located close to Wal-Mart's headquarters in Bentonville, Arkansas. In an empirical study of purchasing managers in North American manufacturing firms, Handfield and Bechtel (2002) found that efforts by the buying firm to build trust resulted in more responsive behavior by suppliers even when buyers had no power over suppliers.

In addition, the results also show that LEs are likely to be more successful in building relationships with their customers. Recent studies showed that LEs are more likely to form tight relationships with their customers because they are able to invest in high-end technologies that help them understand and better serve their customers (Sophie Lee et al., 2000; Sinclair et al., 1996). With high-end technologies, large firms such as Levi's, Nike, and Dell are able to enhance manufacturing processes to match the customer needs. The applications of technologies can enhance efficiency and precision of manufacturing equipment or facilitate the application of advanced manufacturing technology (AMT) and flexible manufacturing (Ho, 1996).

The next issue addressed in this study regards the level of mass customization. The results show definite advantages of the larger firms in offering mass customization to customers. This is consistent with previous studies (Choi \&Krause, 2006; Malhotra \& Grover, 2003; Gibbons, 2005). According to the resource-based theory, LEs have strong financial resources and IT capabilities to enforce the stability of the supply chain. Since SCI is capital intensive, it is likely that larger size firms are likely to have better infrastructures that support the integration initiatives. It has been reported in the literature that LEs can expand their large size supply chains without losing power, by enforcing the adoption of information technologies. Lee, Padmanabhan, and Whang (1997a, 1997b, 2004) suggest that large firms can achieve higher level of integration because they can afford technology implementations such as VMI (vendor managed inventory), CMI (co-managed inventory), JMI (jointly-managed inventory), CPFR (collaborative planning, 
forecasting, and replenishment), collaborative commerce, and CTM (collaborative transport management). With the help of communication technologies, a virtual supply chain is able to control all aspects of supply, production, and distribution through contracts and franchise arrangements (Schroeder, 2007) and bring both higher quality and lower costs to the customer (Larson and Kulchitsky, 1998). IT makes it virtually possible for buying firms to manage the large number of intermediaries in a supply chain from almost anywhere. Prahalad and Hamel (1994) and Hammer (2001) suggest that LEs such as GM, Ford, and Wal-Mart can achieve effective vertical integration when each participant concentrates on processes it performs best, leaving the rest to others. The ideal situation is that the entire process across the supply chain is designed, managed, and coordinated as a unit.

\section{Limitations of the study}

While the current research made significant contributions from both a theoretical and practical point of view, it also has limitations. First, because of the limited number of observations (220), the revalidation of constructs was not carried out in this research. This needs to be addressed in future research. New mailing lists and research methods may be applied to improve the response rate.

Second, Table 5 shows that only 14 percent of the respondents represent top management positions in the form of director or president. This group consists of the most knowledgeable people who can answer questions regarding strategic integration issues. Because of the small number in this group, the extent of supply chain integration found in this study might be skewed downward. This leads to an interesting research question. To what extent does each group of respondents contribute to the total extent of supply chain integration? However, this is beyond the scope of the current study.

Additionally, in this research, individual respondents (manufacturing managers and top management) in an organization were asked to respond to the integration issue dealing with all the participants across the organizations. However, no person in an organization is in charge of all processes across the organization. For example, manufacturing managers are mainly responsible for procuring raw materials and parts, managing production, and therefore, may not be in an appropriate position to answer the supplier/customer-related questions. The main area of manufacturing managers is production and they may not have thorough knowledge of their suppliers, customers, and firm performance. Therefore, the use of single respondent responses may generate some measurement inaccuracy. Future research should seek to utilize multiple respondents from each participating organization as an effort to enhance reliability of research findings. In addition, the study can be expanded to include customers as well as suppliers.

Furthermore, the response rate of approximately 7 percent, even though comparable to similar studies, is considered low. The length of the survey instrument most likely contributed to the low response rate. Because of the time constraints, top management, manufacturing managers and executives are unlikely to participate in the survey. This issue can be addressed in future research by reducing the number of items in the questionnaire and focusing on areas requiring further clarification.

\section{References}

Akacum, A., \& Dale, B.G. (1995). Supplier partnering: Case study experiences. International Journal of Purchasing and Materials Management, 31(1), 38-44.

Anderson, J.C., \& Gerbing, D.W. (1984). The effect of sampling error on convergence, improper solutions, and goodness-of-fit indices for maximum likelihood confirmatory analysis. Psychometrika, 49, 155-173. http://dx.doi.org/10.1007/BF02294170

Armstrong, J.S., \& Overton, T.S. (1977). Estimating nonresponse bias in mail surveys. Journal of Marketing Research, 14(3), 396-402. http://dx.doi.org/10.2307/3150783

Bagchi, P.K., \& Skjoett-Larsen, T. (2002). Organizational integration in supply chains: A contingency approach. Global Journal of Flexible Systems Management, 3(1), 1-10.

Barringer, B. R. (1997). The Effects of Relational Channel Exchange on the Small Firm: A Conceptual Framework, Journal of Small Business Management, 35: 65-79.

Bask, A.H. \& Juga, J. (2001). Semi-integrated supply chains: towards the new era of supply chain management, International Journal of Logistics: Research Applications, 4(2): 137-152. http://dx.doi.org/10.1080/13675560110059434

Bertrand, K. (1986). The just-in-time mandate, Business Marketing, Vol. 71: 44-55. 
Blenckhorn, D. L. \& Noon, A. H. N. (1990). What it take to supply Japanese OEMs.Industrial Marketing Management, Vol. 19(1): 21-30. http://dx.doi.org/10.1016/0019-8501(90)90024-P

Boynton, A.C., Zmud, R.W. \& Jacobs, G.C. (1994). The influence of IT management practice on IT use in large organizations. MIS Quarterly, 18(3), 299-318. http://dx.doi.org/10.2307/249620

Bradley, F., Meyer, R., \& Gao, Y. (2006). Use of supplier-customer relationships by SMEs to enter foreign markets, Industrial Marketing Management, 35(6): 652-665. http://dx.doi.org/10.1016/j.indmarman.2005.05.005

Braunscheidel, M. \& Suresh, N. (2009). The organizational antecedents of a firm's supply chain agility for risk mitigation and response. Journal of Operations Management, 27(2), 119-140. http://dx.doi.org/10.1016/j.jom.2008.09.006

Byrne, B.M. (1989). A primer of LISREL: Basic applications and programming for confirmatory factor analytic models, New York: Springer-Verlag.

Caskey, K., Hunt, I. \& Browne, J. (2001). Enabling SMEs to Take Full Advantage of e-business, Journal of Production Planning and Control, 12(5): 548-557. http://dx.doi.org/10.1080/09537280110042891

Chen, M. \& Hambrick, D. (1995). Speed, stealth, and selective attack: How small firms differ from larger firms in competitive behavior, Academy of Management Journal, 38: 453-482. http://dx.doi.org/10.2307/256688

Chin, W.W. (1998). Issues and opinion on structural equation modeling. MIS Quarterly, 22(1).

Choi, T.Y. \& Krause, D.R. (2006). The supply base and its complexity: implications for transaction costs, risks, responsiveness, and innovation, Journal of Operations Management, 24(5): 637-652. http://dx.doi.org/10.1016/j.jom.2005.07.002

Dilts, J. C. \& Prough, G. E. (1989). Strategic options for environmental management: A comparative study of small vs. large enterprises.Journal of Small Business Management, 27(3): 31-38.

Dyer, J.H., Cho, D.S., \& Chu, W. (1998).Strategic supplier segmentation: the next 'best practice' in supply chain management, California Management Review, 40: 57-77. http://dx.doi.org/10.2307/41165933

Fisher, M. (1997). What is the right supply chain for your product?, Harvard Business Review, March-April, 105-116.

Flint, D.J., Woodruff, R.B., \& Gardial, S.F. (1997). Customer value change in industrial marketing relationships, Industrial Marketing Management, 22(1): 163-175. http://dx.doi.org/10.1016/S0019-8501(96)00112-5

Frohlich, M.T. \& Westbrook, R. (2001). Arcs of integration: an international study of supply chain strategies, Journal of Operations Management, 19, 185-200. http://dx.doi.org/10.1016/S0272-6963(00)00055-3

Frohlich, M.T. (2002). e-Integration in the supply chain: Barriers and Performance, Decision Sciences, 33(4): 537-555. http://dx.doi.org/10.1111/j.1540-5915.2002.tb01655.x

Frohlich, M.T. \& Westbrook, R. (2002). Demand chain management in manufacturing and services: web-based integration, drivers, and performance, Journal of Operations Management, 20: 729-745. http://dx.doi.org/10.1016/S0272-6963(02)00037-2

Fornell, C. \& Larcker, D.F. (1981). Evaluating structural equation models with unobservable variables and measurement error. Journal of Marketing Research, 18(1), 39-50. http://dx.doi.org/10.2307/3151312

Gibbons. (2005). Incentives between firms (and within). Management Science, 51(1): 2-17.

Giunipero, L.C. \& Brewer, D.J. (1993, winter). Performance based evaluation systems under total quality management, International Journal of Purchasing and Materials Management, 29(1), 35-41.

Hair, J.F., Anderson, R.E., Tatham, R.L., \& Black, W.C. (1998). Multivariate Data Analysis. Fifth Edition, Macmillan Publishing Company, New York.

Hammer, M. (2001). The Agenda. What Every Business Must Do to Dominate the Decade, Random House Business Books, London.

Handfiled, R.B. \& Bechtel, C. (2002). The role of trust and relationship structure in improving supply chain responsiveness, Industrial Marketing Management, 31: 367-382. http://dx.doi.org/10.1016/S0019-8501(01)00169-9

Handfield, R.B., Krause, D.R., Scannell, T.V., \& Monczka, R.M. (2000). Avoid the pitfalls in supplier development, Sloan Management Review, 41, 37-49. 
Harland, C.M., Lamming, R.C., Zheng, J., \& Johnsen, T.E. (2001). A taxonomy of supply networks, The Journal of Supply Chain Management, 37(4): 21-27. http://dx.doi.org/10.1111/j.1745-493X.2001.tb00109.x

Harrison, A. (1992). Just-in-time manufacturing in perspective. London: Prentice Hall.

Ho, C. (1996). Information technology implementation strategies for manufacturing organizations: A strategic alignment approach, International Journal of Operations \& Production Management, 16(7), 1996, 77-100. http://dx.doi.org/10.1108/01443579610119171

Jayaram, J., Kannan, V.R., \& Tan, K.C. (2004). Influence of initiations on supply chain value creation, International Journal of Production Research, 42(20): 4377-4399. http://dx.doi.org/10.1080/00207540410001716516

Johnson, J.L. (1999). Strategic integration in industrial distribution channels: managing the inter-firm relationship as a strategic asset. Academy of Marketing Science, 5: 4-18. http://dx.doi.org/10.1177/0092070399271001

Kalwani, M.U., \& Narayandas, N. (1995, January). Long-term manufacturer-supplier relationships: Do they pay off for supplier firm?, Journal of Marketing, 59: 1-16. http://dx.doi.org/10.2307/1252010

Khurana, A. \& Talbot, B. (1998). The internationalization process model through the lens of the global color picture tube industry, Journal of Operations Management, 16(2-3): 215-239. http://dx.doi.org/10.1016/S0272-6963(97)00039-9

Kopczak, L.R. (1997). Logistics partnerships and supply chain restructuring: survey results from the US computer industry, Production and Operations Management, 6(2): 226-247.

Koufteros, X. (1999). Testing a model of pull production: a paradigm for manufacturing research using structural equation modeling. Journal of Operations Management, 17(4), 467-488. http://dx.doi.org/10.1016/S0272-6963(99)00002-9

Koufteros, X., Vonderembse, M.A. \& Doll, W. (2001). Concurrent engineering and its consequences. Journal of Operations Management, 19(1), 97-115. http://dx.doi.org/10.1016/S0272-6963(00)00048-6

Lambert, D. \& Garcia-Dastugue, S.J. (2006). Cross-functional business processes for the implementation of service-dominant logic. In R. Lusch and S. Vargo, eds. The Service-Dominant Logic of Marketing. Armonk, New York: M.E.Sharpe, 150-165.

Lamming, R. (1993). Beyond Partnership: Strategies for Innovation and Lean Supply Chain, Prentice-Hall, London.

Larson, P.D. \& Kulchitsky, J.D. (1998). Single sourcing and supplier certification, Industrial Marketing Management, 27: 73-81. http://dx.doi.org/10.1016/S0019-8501(97)00039-4

Leavy B. (1990). The supplier relationship and competitive strategy, In H.E. Glass (Ed.), Handbook of business strategy-1989/90 yearbook (pp.16:1-16:5). Gorham and Lamont, Boston: Warren.

Lee, H. L., \& Billington, C. (1992). Managing supply chain inventory: Pitfalls and opportunities, Sloan Management Review, Spring: 65-73.

Lee, H.L., Padmanabhan, V., \& Whang, S. (1997a). Information distortion in a supply chain: The bullwhip effect, Management Science, 43(4): 546-558. http://dx.doi.org/10.1287/mnsc.43.4.546

Lee, H.L., Padmanabhan, V., and Whang, S. (1997b). The bullwhip effect in supply chains, Sloan ManagementReview, 38(3, Spring): 93-102.

Lee, H.L., Padmanabhan, V., \& Whang, S. (2004). Comments on "Information distortion in a supply chain: The bullwhip effect, Management Science, 50(12): 1887-1893. http://dx.doi.org/10.1287/mnsc.1040.0305

Lascelles, D.M. and Dale, B.G. (1989). The buyer-supplier relationship in total quality management.International Journal of Purchasing and Materials Management, 25(3): 10-19.

Malhotra, M.K. \& Grover, V. (2003). Transaction cost framework in operations and supply chain management research: theory and measurement, Journal of Operations Management, 21: 457-473. http://dx.doi.org/10.1016/S0272-6963(03)00040-8

Matthyssens, P. \& Bulte, C.V.D. (1994). Getting closer and nicer: Partnerships in the supply chain. Long Range Planning Vol. 27(1): 72-83. http://dx.doi.org/10.1016/0024-6301(94)90008-6

Morrissey, J. W., \& Pittaway, L. (2006). Buyer-Supplier Relationships in Small Firms, International Small Business Journal, 24(3): 272-298. http://dx.doi.org/10.1177/0266242606063433 
Narasimhan, R. \& Das, A. (1999). An empirical investigation of the contribution of strategic sourcing to manufacturing flexibilities and performance, Decision Sciences, 30(3): 683-718. http://dx.doi.org/10.1111/j.1540-5915.1999.tb00903.x

Narasimhan, R., \& Jayaram, J. (1998). Causal linkages in supply chain management: An exploratory study of North American manufacturing firms, Decision Sciences, 29(3): 579-605. http://dx.doi.org/10.1111/j.1540-5915.1998.tb01355.x

Narasimhan, R. \& Kim, S.W. (2002). Effect of supply chain integration on the relationship between diversification and performance: evidence from Japanese and Korean firms, Journal of operations management, 20, 303-323. http://dx.doi.org/10.1016/S0272-6963(02)00008-6

Normann, R. \& Ramirez, R. (1993). From value chain to value constellation: designing interactive strategy. Harvard Business Review, 71(4), 65-77.

Nunnally, J.C. (1978). Psychometric Theory, McGraw Hill: New York.

O’Neal, C. \& Bertrand, K. (1991). Developing a winning J.I.T. marketing strategy- the industrial marketer's guide. Englewood Cliffs, New Jersey: Prentice Hall.

Petersen, K.J., Handfield, R.B., \& Ragatz, G.L. (2005). Supplier integration into new product development: coordinating product, process, and supply chain design, Journal of Operations Management, 23: 371-388. http://dx.doi.org/10.1016/j.jom.2004.07.009

Powers, T.L., Sterling, J.U., \& Wolter, J.F. (1988). Marketing and manufacturing conflict: sources and resolution, Production and Inventory Management Journal: 56-60.

Prahalad, C.K. \& Hamel, G. (1994). Strategy as a field of study: why search for a new paradigm, Strategic Management Journal, 15(Special): 5-16.

Quayle, M. (1999). The challenge for UK SMEs in the twenty-first century, International Journal of Operations and Production Management, 22(10): 1148-1161. http://dx.doi.org/10.1108/01443570210446351

Ragatz, G.L., Handfield, R.B., \& Scannell, T.V. (1997). Success factors for integrating suppliers into new production development, Journal of Product Innovation Management, 14: 190-202. http://dx.doi.org/10.1016/S0737-6782(97)00007-6

Raudenbush, S.W. \& Bryk, A.S. (2002). Hierarchical linear modeling: Applications and Data Analysis Methods 2nd Edition, Sage Publications, New Delhi, London: International Educational and Professional Publisher.

Reukert, R.W. \& Walker, O.C., JR. (1987). Marketing's interaction with other functional units: a conceptual framework and empirical evidence, Journal of Marketing, 51: 1-19. http://dx.doi.org/10.2307/1251140

Rho, B.H., Hahm, Y.S., \& Yu, Y.M. (1994). Improving interface congruence between manufacturing and marketing in industrial-product manufacturers, International Journal of Production Economics, 37: 27-40. http://dx.doi.org/10.1016/0925-5273(94)90005-1

Roth, A.V. (1998). The second generation of quality: global supply chain integration in Japan and the United States, In: Cortada, J.W., Woods, J.A. (Eds), The Quality Yearbook. McGraw-Hill, NY, 38.1-38.44.

Schroeder, R.G. (2007). Operations management: Contemporary concepts and cases, $3^{\text {rd }}$ Edition, McGraw-Hill, NY.

Segars, A.H. (1997). Assessing the unidimensionality of measurement: a paradigm and illustration within the context of information systems research. Omega, 25(1), 107-121. http://dx.doi.org/10.1016/S0305-0483(96)00051-5

Shin, H., Collier, D.A., \& Wilson, D.D. (2000). Supply management orientation and supplier/buyer performance, Journal of Operations Management, 18: 317-333. http://dx.doi.org/10.1016/S0272-6963(99)00031-5

Simchi-Levi, D., Kaminsky, O., \& Simchi-Levi, E. (2003). Designing and Managing Supply Chain: Concepts, Strategies, and Case Studies, $2^{\text {nd }}$ Ed., Irwin/McGraw-Hill, New York, NY.

Sinclair, D., Hunter, L., \& Beaumont, P. (1996). Models of customer-supplier relations. Journal of General Management Vol. 22(2), 56-75.

Sophie Lee, C.H., Barua, A., \& Whinston, A.B. (2000). The complementary of mass customization and electronic commerce, Econ. Innov. New Tech., 9, 81-109. http://dx.doi.org/10.1080/10438590000000005

Steger-Jensen, K. \& Svensson, C. (2004). Issue of mass customisation and supporting IT-solutions. Computers In Industry, 54, 83-103. http://dx.doi.org/10.1016/j.compind.2003.07.007 
Stock, G.N., Greis, N.P, \& Kasarda, J.D. (2000). Enterprise logistics and supply chain structure: The role of fit, Journal of Operations Management, 18(5): 531-547. http://dx.doi.org/10.1016/S0272-6963(00)00035-8

Swafford, P.M., Ghosh, S. \& Murthy, N. (2006). The antecedents of supply chain agility of a firm: scale development and model testing. Journal of Operations Management, 24(2), 170-188. http://dx.doi.org/10.1016/j.jom.2005.05.002

Taps, S.B. \& Steger-Jensen, K. (2007). Aligning supply chain design with manufacturing strategies in developing regions. Production Planning \& Control, 18(6), 475-486. http://dx.doi.org/10.1080/09537280701495021

Tu, Q., Vonderembse, M.A. \& Ragu-Nathan, T.S. (2001). The impact of time-based manufacturing practices on mass customization and value to customer. Journal of Operations Management, 19(2), 201-217. http://dx.doi.org/10.1016/S0272-6963(00)00056-5

Tu, Q., Vonderembse, M.A. \& Ragu-Nathan, T.S. (2004a). Manufacturing practices: antecedents to mass customization. Production Planning and Control, 15(4), 373-380. http://dx.doi.org/10.1080/0953728042000238827

Tu, Q., Vonderembse, M.A., Ragu-Nathan, T.S., \& Ragu-Nathan, B. (2004b). Measuring modularity-based manufacturing practices and their impact on mass customization capability: A Customer-Driven Perspective. Decision Sciences, 35(2), 147-168. http://dx.doi.org/10.1111/j.00117315.2004.02663.x

Turnbull, P., Oliver, N., \& Wilkinson, B. (1992). Buyer-supplier relations in the UK automotive industry: strategic implications of the Japanese manufacturing model, Strategic Management Journal, 13: 159-168. http://dx.doi.org/10.1002/smj.4250130207

Vickery, S.K., Jayaram, J., Droge, C., \& Calantone, R. (2003). The effects of an integrative supply chain strategy on customer service and financial performance: an analysis of direct versus indirect relationships, 21: 523-539.

Wagner, S.M. (2003). "Intensity and managerial scope of supply chain integration", The Journal of Supply Chain Management, 39(4): 4-15. http://dx.doi.org/10.1111/j.1745-493X.2003.tb00160.x

Wood, A. (1997). Extending the supply chain: Strengthening links with IT, Chemical Week, 159(25): 26.

Xu, L., \& Beamon, B. M. (2006). Supply Chain Coordination and Cooperation Mechanisms: An Attribute-Based Approach, Journal of Supply Chain Management, 42(1): 4-12. http://dx.doi.org/10.1111/j.1745-493X.2006.04201002.x

Zhang, Cheng \& Zhang, Chenghong. (2007, January). Design and simulation of demand information sharing in a supply chain.Simulation Modeling Practice and Theory, 15(1): 32-46. http://dx.doi.org/10.1016/j.simpat.2006.09.011 Zipkin, P. (1991). Does manufacturing need a JIT revolution? Harvard Business Review, 69(1): 40-50. 
Appendix A. Measurement of research constructs (dropped items in italics).

Customer and Supplier Integration (CI and SI): The following statements describe the extent to which the manufacturing department interacts with its customers and suppliers. Please circle the appropriate number to indicate the extent to which you agree or disagree with each statement as applicable to your unit.
CI1 The willingness of customers to share their market demands
CI2 The participation level of customers in product development processes
CI3 The participation level of customers in finished goods distribution processes
CI4 The extent of follow-up with customers for feedbacks
CI5 The level of customer involvement in preparing business plans
CI6 The participation level of customers in manufacturing processes
SI1 The participation level of suppliers in manufacturing processes
SI2 The participation level of suppliers in production planning processes
SI3 The participation level of suppliers in product development processes
SI4 The participation level of suppliers in logistics processes
SI5 The level of cross-over of activities between our firm and our suppliers
SI6 The level of supplier involvement in preparing our business plans

Mass Customization (MC): The following statements measure firm's capability to customize products inexpensively and quickly. Please circle the appropriate number that best indicates your perception of the relative capabilities of your firm as compared to the industry average

MC1 Our capability of customizing products at low cost is

MC2 Our capability of translating customer requirements into technical designs quickly is

MC3 Our capability of adding product variety without increasing cost is

MC4 Our capability of customizing products while maintaining a large volume is

MC5 Our capability of setting up for a different product a low cost is

MC6 Our capability of adding product variety without sacrificing overall production volume is

MC7 Our capability of changeover to a different product quickly is

MC8 Our capability of customizing products on a large scale is

MC9 Our capability of responding to customization requirements quickly is

Firm Performance (FP): The following statements measure overall performance of your firm. Please circle the appropriate number that best indicates the level of your firm's overall performance.

FP1 Customer retention rate.

FP2 Sales growth.

FP3 Return on investment.

FP4 Overall competitive position.

FP5 Production throughput times. 
Table 1. Definition and references for customer integration, supplier integration, and mass customization

\begin{tabular}{||l|l|l||}
\hline Variable & Definition & References \\
\hline $\begin{array}{l}\text { Integration } \\
\text { part in value creating activities and } \\
\text { processes that had previously been in } \\
\text { the domain of the firm. }\end{array}$ & $\begin{array}{l}\text { Koufteros et al., 2005; Kim and Narasimhan, } \\
\text { 2002; Narasimhan and Kim, 2002; Narasimhan } \\
\text { and Jayaram, 1998; Narasimhan and Das, 1999; } \\
\text { Frohlich and Westbrook, 2001; Frohlich and } \\
\text { Westbrook, 2002; Frohlich, 2002;Wikstrom, } \\
\text { 1996; Zipkin, 2001. }\end{array}$ \\
\hline $\begin{array}{l}\text { Supplier } \\
\text { Integration }\end{array}$ & $\begin{array}{l}\text { The extent to which vendors form } \\
\text { cooperative relationships by taking } \\
\text { part in activities and processes that } \\
\text { had previously been in the domain of } \\
\text { the firm. }\end{array}$ & $\begin{array}{l}\text { Piller et al., 2004; Sanders, 2005; Sanders and } \\
\text { Premus, 2005; Tracey et al., 1999; Narasimhan } \\
\text { and Das, 1999; Narasimhan and Jayaram, 1998; } \\
\text { Kim and Narasimhan, 2002; Narasimhan and } \\
\text { Kim, 2002; Petersen et al., 2005a; Petersen et al., } \\
\text { 2005b; Johnson, 1999; Frohlich and Westbrook, } \\
\text { 2001; Frohlich and Westbrook, 2002; Frohlich, } \\
\text { 2002. }\end{array}$ \\
\hline $\begin{array}{l}\text { Mass } \\
\text { Customization }\end{array}$ & $\begin{array}{l}\text { The ability of a firm to produce a } \\
\text { variety of customized products } \\
\text { quickly, on a large scale, and at a } \\
\text { cost of comparable to mass } \\
\text { production. }\end{array}$ & $\begin{array}{l}\text { Pine, 1993; Pine, 1993; Tseng and Jiao, 2001; } \\
\text { Piller, 2003; Frank and Piller, 2003; O'Grady, } \\
\text { 1999; Sophie Lee et al., 2000; Lau, 1995; Tu et } \\
\text { al., 2001.; Tu et al., 2004a; Tu et al., 2004b. }\end{array}$ \\
\hline $\begin{array}{l}\text { The ability of a firm to fulfill its } \\
\text { market and financial goals. }\end{array}$ & $\begin{array}{l}\text { Yamin et al., 1999; Frohlich, 2002; Narasimhan } \\
\text { and Kim, 2002; Wisner, 2003; Rosenzweig et al, } \\
\text { 2003; Tegarden et al., 2005; Taps and } \\
\text { Steger-Jensen, 2007. }\end{array}$ \\
\hline Performance
\end{tabular}

Table 2. Measurement model factor loadings

\begin{tabular}{lllll}
\hline First order construct & Indicators & $\begin{array}{l}\text { First order } \\
\text { loadings }(\lambda)\end{array}$ & Indicators & $\begin{array}{l}\text { First order } \\
\text { loadings }(\lambda)\end{array}$ \\
\hline & & & & \\
Customer Integration (CI) & CI1 & .72 & CI3 & .80 \\
4 indicator items & CI2 & .79 & CI4 & .79 \\
Supplier Integration (SI) & SI1 & .78 & SI4 & .82 \\
6 indicator items & SI2 & .85 & SI5 & .83 \\
& SI3 & .78 & SI6 & .81 \\
Mass Customization (MC) & & & & \\
7 indicator items & MC1 & .77 & MC5 & .80 \\
& MC2 & .74 & MC6 & .81 \\
& MC3 & .83 & MC7 & .76 \\
Firm Performance (FP) & MC4 & .77 & & \\
4 indicator items & & & & .77 \\
\hline
\end{tabular}


Table 3. Reliability Analysis $(n=220)$

\begin{tabular}{llll}
\hline Scale & $\begin{array}{l}\text { Cronbach's } \\
\boldsymbol{\alpha m i n} \geq 0.70\end{array}$ & $\begin{array}{l}\text { Composite } \\
\text { Reliabilitymin } \geq 0.70\end{array}$ & $\begin{array}{l}\text { Average Variance Extractedmin } \\
\geq 0.50\end{array}$ \\
\hline Customer Integration & .78 & .86 & .60 \\
Supplier Integration & .90 & .92 & .66 \\
Mass Customization & .90 & .92 & .62 \\
Firm Performance & .80 & .87 & .63 \\
\hline
\end{tabular}

Table 4. Discriminant validity (square root of AVE on diagonal in bold)

\begin{tabular}{lllll}
\hline & $\begin{array}{l}\text { Customer } \\
\text { Integration }\end{array}$ & $\begin{array}{l}\text { Supplier } \\
\text { Integration }\end{array}$ & $\begin{array}{l}\text { Mass } \\
\text { Customization }\end{array}$ & $\begin{array}{l}\text { Firm } \\
\text { Performance }\end{array}$ \\
\hline Customer Integration & $\mathbf{. 7 7 5}$ & & & \\
Supplier Integration & .539 & $\mathbf{. 8 1 2}$ & & \\
Mass Customization & .373 & .248 & $\mathbf{. 7 8 7}$ & \\
Firm Performance & .276 & .254 & .381 & $\mathbf{. 7 9 4}$ \\
& & & & \\
\hline
\end{tabular}

Table 5. Sample Characteristics

\begin{tabular}{|l|ll|}
\hline \multirow{5}{*}{1.} & Job Titles (220) & \\
\cline { 2 - 3 } & CEO/President & $6.82 \%(15)$ \\
& Director & $7.27 \%(16)$ \\
& Manager & $53.18 \%(117)$ \\
& Supervisor & $27.27 \%(60)$ \\
& Engineer & $4.55 \%(10)$ \\
& Other & $0.91 \%(2)$ \\
\hline \multirow{5}{*}{2.} & Job Functions (261) (respondents may have more than one job functions) \\
\cline { 2 - 3 } & Corporate Executive & $6.51 \%(17)$ \\
& Purchasing & $6.13 \%(16)$ \\
& Transportation & $2.30 \%(6)$ \\
& Manufacturing Production & $41.38 \%(108)$ \\
& Distribution & $1.15 \%(3)$ \\
& Sales & $6.13 \%(16)$ \\
& Unidentified & $13.41 \%(35)$ \\
& Other & $22.99 \%(60)$ \\
\hline \multirow{5}{*}{3.} & Level of Education (220) \\
\cline { 2 - 3 } & High School & $10.45 \%(23)$ \\
& Two-yearCollege & $20.00 \%(44)$ \\
& Bachelor's Degree & $31.82 \%(70)$ \\
& Master's Degree & $16.36 \%(36)$ \\
& Doctor's Degree & $1.36 \%(3)$ \\
& Unidentified & $15.91 \%(35)$ \\
& Other & $4.09 \%(9)$ \\
\hline
\end{tabular}


Table 6. Test of Non-Response Bias

\begin{tabular}{|c|c|c|c|c|c|}
\hline \multirow{2}{*}{\multicolumn{2}{|c|}{ Variables }} & First wave & \multirow{2}{*}{$\begin{array}{l}\text { Second wave } \\
\text { Expected Freq. } \\
\text { (\%) }\end{array}$} & \multirow{2}{*}{$\begin{array}{l}\text { Second wave } \\
\begin{array}{l}\text { Observed Freq. } \\
\text { (\%) }\end{array}\end{array}$} & \multirow{2}{*}{$\begin{array}{l}\text { Chi-square } \\
\text { Test }\end{array}$} \\
\hline & & $\begin{array}{l}\text { Frequency } \\
\text { (\%) }\end{array}$ & & & \\
\hline \multicolumn{6}{|c|}{ Sales Volume in millions of \$ (220) } \\
\hline \multicolumn{2}{|l|}{$<5$} & 20 & 7 & 0 & \multirow{7}{*}{$\begin{array}{l}\chi^{2}=10.78 \\
\mathrm{df}=6 \\
\mathrm{p}>.10\end{array}$} \\
\hline \multicolumn{2}{|l|}{5 to $<10$} & 10 & 5 & 6 & \\
\hline \multicolumn{2}{|l|}{10 to $<25$} & 28 & 13 & 11 & \\
\hline \multicolumn{2}{|l|}{25 to $<50$} & 13 & 8 & 12 & \\
\hline \multicolumn{2}{|l|}{50 to $<100$} & 20 & 9 & 6 & \\
\hline \multicolumn{2}{|l|}{ Over 100} & 33 & 17 & 20 & \\
\hline \multicolumn{2}{|c|}{ Unidentified } & 24 & 13 & 17 & \\
\hline \multirow{2}{*}{ Variables } & \multirow{2}{*}{ Mean } & First wave & Second wave & \multirow{2}{*}{$\mathrm{t}$ - Test } & \multirow{2}{*}{ p - value } \\
\hline & & Total score & Total score & & \\
\hline CI & 3.41 & 18.87 & 19.61 & 1.22 & 0.23 \\
\hline SI & 2.75 & 16.72 & 16.61 & 0.16 & 0.88 \\
\hline
\end{tabular}

The calculation formula $\chi^{2}=\sum^{\left(f_{e}-f_{o}\right)^{2} / f_{e}}$

Table 7. Hypotheses Testing Results

\begin{tabular}{|c|c|c|c|c|c|}
\hline \multicolumn{6}{|c|}{ Interaction effects of $\mathbf{S}$ and $\mathbf{S C R}$ on $\mathbf{M C}(\mathrm{H} 1)$} \\
\hline Variables & Coefficient & Std & t-value & Sig & Supported \\
\hline$\beta_{0}$ & 2.800 & 0.126 & 22.301 & 0.0001 & \multirow[b]{2}{*}{ H1 is supported. } \\
\hline $\mathrm{SCR} * \mathrm{~S}$ & 0.194 & 0.044 & 4.365 & 0.0001 & \\
\hline \multicolumn{6}{|c|}{ Interaction effects of $\mathbf{S}$ and $\mathbf{C I}$ on $\mathbf{O P}(\mathrm{H} 2)$} \\
\hline Variables & Coefficient & Std & t-value & & Supported \\
\hline$\beta_{0}$ & 3.482 & 0.109 & 32.081 & 0.0001 & \\
\hline $\mathrm{CI} * \mathrm{~S}$ & 0.087 & 0.034 & 2.602 & .01 & $\mathrm{H} 2$ is supported. \\
\hline \multicolumn{6}{|c|}{ Interaction effects of S and SI on OP (H3) } \\
\hline Variables & Coefficient & Std & t-value & & Supported \\
\hline$\beta_{0}$ & 3.485 & 0.100 & 34.754 & 0.0001 & \\
\hline $\mathrm{SI} * \mathrm{~S}$ & 0.108 & 0.038 & 2.838 & 0.005 & $\mathrm{H} 3$ is supported. \\
\hline \multicolumn{6}{|c|}{ Interaction effects of $\mathbf{S}$ and $\mathrm{MC}$ on $\mathrm{OP}(\mathrm{H} 4)$} \\
\hline Variables & Coefficient & Std & t-value & & Supported \\
\hline$\beta_{0}$ & 3.419 & 0.105 & 32.488 & 0.0001 & \\
\hline $\mathrm{MC} * \mathrm{~S}$ & 0.111 & 0.033 & 3.362 & 0.001 & $\mathrm{H} 4$ is supported. \\
\hline
\end{tabular}




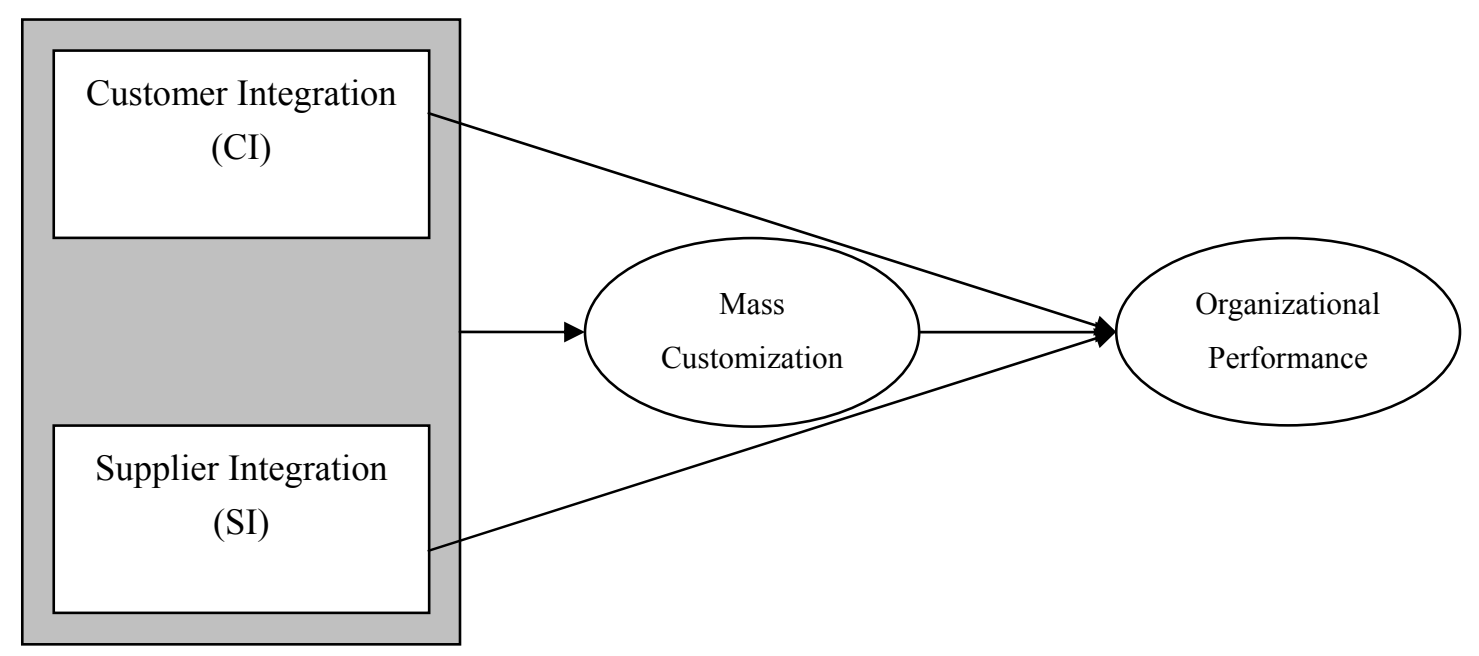

Figure 1. Supply Chain Relationships and Mass Customization Framework

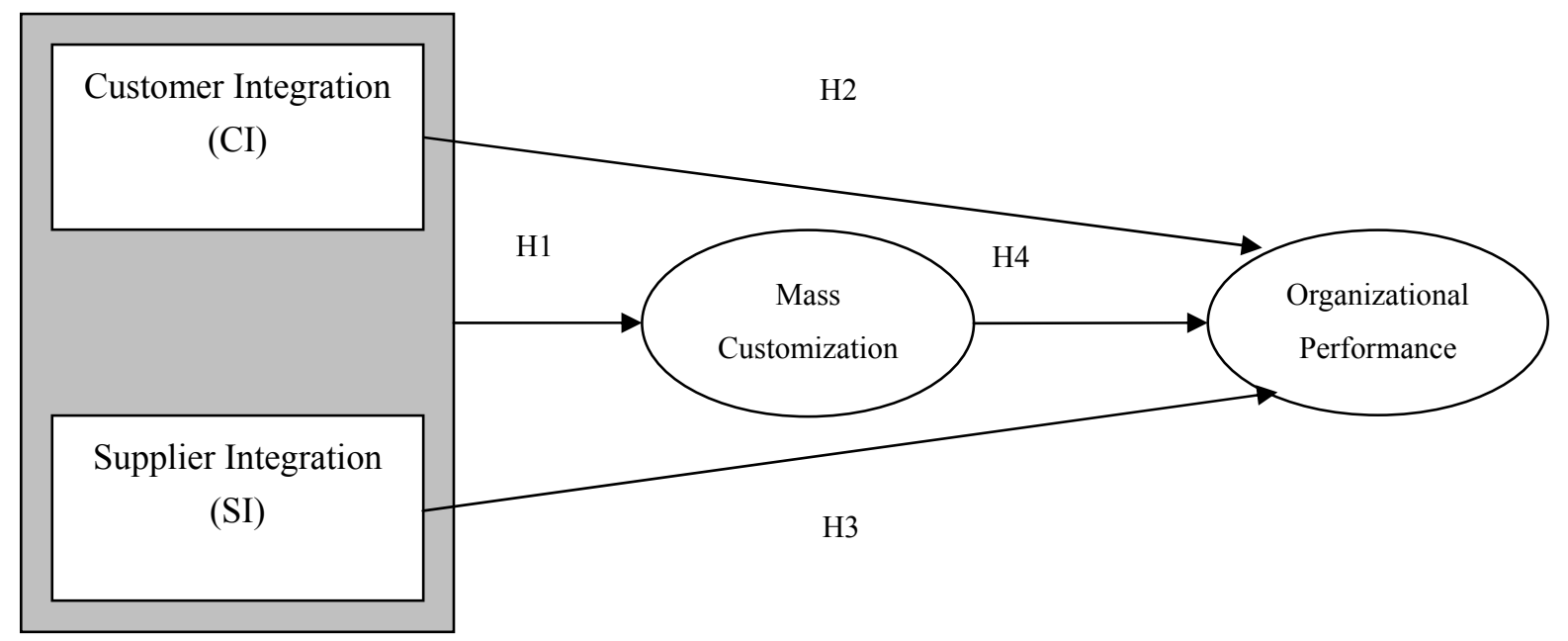

Figure 2. Supply Chain Relationships and Mass Customization in SMEs VS LEs Framework 